\title{
Drooms Store Strategy To Win Business Competition On E-Commerce Lazada
}

\author{
Asep Sugara ${ }^{1)}$ \\ asepsugara01@gmail.com \\ MD. Sukamto') \\ mdsukamto66@gmail.com \\ Rida Ramdani ${ }^{3}$, \\ rida9900@gmail.com \\ 1)2)3)STISIP Yuppentek Tangerang
}

\begin{abstract}
This study aims to determine the Droom Store strategy in winning business competition in Lazada E-Commerce and increasing customer satisfaction. The analytical approach used is to use a qualitative approach. Where the owner of Drooms Store used as key informants with data collection using triangulation techniques.

The results of research at Drooms Store using the techniques above, strategies that can win business competition in Lazada E-Commerce are product selection strategies which are the basis of product sales in which there are product research activities, namely where the seller determines the scale of the benefits of a product. product, then the price of the product, and also the target market. Product advertising strategy which is the second stage after the product selection strategy where this product advertising strategy can reach consumers and attract consumers to buy products. Then there is a product promotion strategy that aims to boost sellers to increase. A business analysis strategy that aims to control the business at Drooms Store. In other words, Lazada's E-commerce for the strategy that we will use has been very well supported by Lazada.
\end{abstract}

Keywords: E-commerce Lazada ${ }^{1}$, Drooms Store ${ }^{2}$, Strategy ${ }^{3}$. 


\section{PRELIMINARY}

The current development shows a trend of shifting forms of marketing from static advertising to digital advertising. This form of static advertisement can be in the form of leaflet distribution, poster installation, banners to billboards, baligo lighting and neon boxes. Meanwhile, forms of digital advertising such as videotron, megatron and advertisements use television or web media that lead to dynamic advertisements. Both types of advertising use above are high-cost (expensive). Therefore, now people have started to take advantage of social media such as Facebook, Twitter, WhatsApp, Line, TikTok, and Instagram, which were personal communication media, and have used them a lot as media for product marketing.

Along with the development of information and communication technology, there are many positive sides for individuals, business organizations and government organizations. Where the use of cellphones is now a primary need for individuals and these individuals can access various information including information about a product. This is also used by E-Commerce business organizations in marketing products. Lots of E-Commerce in Indonesia, there are more than 20 local and foreign businesses. There is a massive increase in mobile visits to E-Commerce in Southeast Asia. Within 12 months, mobile traffic has increased by an average of $19 \%$. Now mobile traffic accounts for an average of $72 \%$ of total web traffic, and Indonesia is the country with the highest share of mobile traffic, which is $87 \%$, this has a major impact on the development of E-Commerce in Indonesia.

Business activities using the internet and gadgets are a major innovation to enter the market in cyberspace which is commonly called electronic business and commerce (e-business and E-Commerce). The creation of this online market is a new way for small businesses or small and medium enterprises (SMEs) to enter the market and compete with other business organizations.

In the last three years (2018 to 2020 ) itself has been the best period to shop online. E-Commerce players are competing to spoil their customers with various shopping festivals that are claimed to be full of discounts and cashbacks. At least, there are six online shopping festival agendas held in Indonesia this year. This kind of sales agenda is believed to be able to attract a massive number of transactions. For example, the recently passed Harbolnas (12-12) was able to record transactions of up to Rp. 6.8 trillion in just two days of the event.

Lazada is still the most popular in Southeast Asia because it controls 25\% more market share compared to other E-Commerce in this region. However, 2018 does not seem like a satisfying period for Lazada in Indonesia. Domestic consumer visits to Lazada Indonesia's website via desktop and mobile web have been relatively volatile over the past 11 months.

In fact, E-Commerce penetration looked promising at the start of the year thanks to the acquisition and disbursement of US \$ 2 billion from Alibaba in March. Lazada also won 85 million desktop and mobile web visits when it held the Lazada Birthday Fest one month later. However, in the middle of the year the visits on this $E$ Commerce site decreased to a low of 33 million visitors. In fact, Jack Ma's arrival to Indonesia in the middle of the year was not able to increase people's interest to interact more at Lazada. 
The decline in traffic levels on the Lazada site is even more obvious when compared to the number of desktop and mobile web visitors that Shopee has managed to collect so far this year. Reflecting on the period at the beginning of the year, Shopee's performance has increased almost $3 x$, being able to cut the gap with Lazada who is in the top three. In fact, the visitor margin for Lazada and Shopee in January stood at 51 million.

Drooms Store is a home business that uses the internet and E-Commerce as a medium of marketing and sales. A business that is engaged in selling clothes and household appliances is one of the most competitive businesses, so Drooms Store has to innovate in terms of products, as well as marketing and sales strategies. The development of E-Commerce and e-business so far has created many advantages for business organizations. Drooms Store uses E-Commerce lazada as a marketing and sales medium.

Thus it can be formulated that rum u s an issue in this study is what the strategy undertaken by Drooms Store for winning the competition with similar products sold by komptitor in E-Commerce Lazada and satisfy the customers? Meanwhile, the purpose of this research is to find out what strategies Drooms Store should do in order to succeed in selling products on Lazada, and increase customer satisfaction.

\section{RESULTS AND DISCUSSION}

Based on the results of researchers' observations on the activities carried out by Drooms Store in managing their shop in E-Commerce Lazada and conducting interviews with Mr. Dadang Romansyah as the owner of Drooms Store about Strategies to Win Business Competition in E-Commerce Lazada, there are several things that are always done at Drooms Store. to achieve it all and the cycle must be continuous.

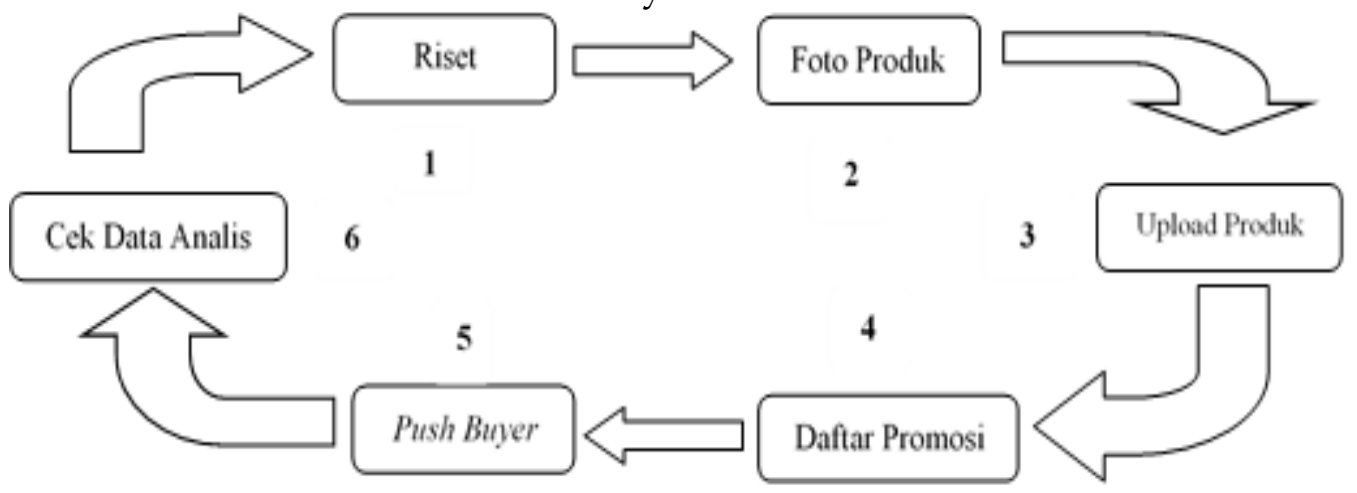

Figure 1. Cycle of the Drooms Store Sales Strategy

Condistion Drooms Store have strategy in winning business competition in ECommerce Lazada and satisfying the consumers as follows.

\section{Product Selection Strategy}

Results of observation on $\mathrm{p}$ Indonesia Economic happens to Drooms Store in ECommerce Lazada of strategy product selection is the most important strategy when running a business e-commerce, because by choosing products that consumers need to be easily anyway marketing of products runs. This selection of the right product must also occur repeatedly because there will be a lot of competition from other sellers selling the same goods. Competition can occur in 
terms of price, product variants that make consumers move to other sellers if they think the product we are selling is less favorable. That way, one way to attract consumers is by providing them with the best products with many variations and all kinds of other needs.

According to Dadang Romansyah as the owner of Drooms Store, when we are going to determine which products to sell, there are several things that must be considered, namely :

a. Benefit scale, which means how much use the goods we choose for consumers, by paying attention to the scale of benefits, the products we sell are products that are sought after by consumers, it's just how we do our product marketing strategies.

b. The price is right, meaning the price does not have to be cheap to get many consumers. Because basically a good price is the price that matches the goods we sell.

c. A broad target market, meaning that you determine a target market that reaches all groups. So that the products we sell have a wide range.

Another thing that is observed is, happened differences in products sold in 2020 and 2019. While in 2019 the pillow into a top product but can not survive in 2020, it became a natural thing in the business of E-Commerce for the level of competition is very tight or consumer purchasing power has changed. Therefore, a product selection strategy is needed to increase turnover as in 2019.

2. Product Advertising Strategy

This product advertising strategy is an additional strategy to reach consumers so that those who need the products we sell can checkout goods from our stores and retain customers who have bought the products we already sell. According to Dadang Romasnyah as the owner of Drooms Store, there are several things that must be considered to improve the product advertising strategy, namely:

a. Display or product photos must be attractive to attract page views from consumers.

b. The title or product name must be catchy and specific so that it is easy to search.

c. Good store decoration can attract attention for consumers to visit the store and see the products we sell.

d. A high sales rate increases the time of product search.

e. Push buyers to give reviews and chat to buyers by attaching shop vouchers to maintain consumer purchasing power.

\section{Seller Voucher Strategy}

The seller voucher strategy is a promotional feature that aims to increase the order conversion rate by creating your own vouchers. In the last 30 days, Drooms Store did not use seller vouchers because sales were not maximal and had no effect on consumer buying interest. Seller voucher had a chance Drooms Store made in 2019.

\section{Free Shipping Strategy}

The free shiping strategy is a promotional feature that also aims to increase sales by eliminating shipping costs for buyers. According to Drooms Store, the free shipping strategy is very attractive to consumers and by doing so sales can increase, but there must still be a strategy implemented so that sales do not have an impact on profits. Compared to other promo features provided by 
Lazada, the free shiping promo is the promo with the most consumers. There is a change in shipping costs from Lazada E-Commerce effective December 16, 2020, after December 12-12 promo. In addition to changes in shipping costs, there is also a change in the latest mechanism for promotion of shipping costs to customers, so that customers must collect free shipping vouchers first if they want to get free shipping.

\section{Lazada's Business Analysis Strategy}

Lazada's Business Analyst is part of the features provided by Lazada ECommerce to make it easier for sellers to increase their promotion, in which there is a dashboard that provides a store's performance results and an overview of different promotional performance in terms of average order value. Sellers can use this data on business analysts to optimize their promotion mechanism. Having a business analyst at Lazada can help sellers make business decisions. The types of analysis business at Lazada consist of:

a. The business analyst dashboard is useful for viewing daily store performance, checking daily revenue and products that sell well on a certain day. So that Drooms Store can measure and target their daily turnover. In the business analysis dashboard, there is also a feature that compares today's income and the previous day, making it easier to manage strategies to increase turnover.

b. Key metrics like the one in the image above are still on the business analyst dashboard which is useful for measuring the total price of orders paid by buyers, including all discounts, store credits, shipping costs, and surcharges. Then the metric key is useful for seeing the number of customers who viewed the shop page, including the home page, all product pages, and other pages in the store we have, in the selected date range. In other words, the key metric shows how much the store reaches consumers, so that with this data, the seller can determine a strategy for how to increase the conversion rate of the store at a certain time.

c. A business analyst list which includes a feature to check the number of customers who viewed the shop page including the home page, all product pages, and other pages in the store. Then it can be seen also page view traffic, namely the number of times customers visit the shop page. So that our analyst business traffic can monitor how much reach the store is and think of strategies to increase sales opportunities.

d. Product business function analysis for product selection strategy, which in this part of all products sold on the attached shop here and have a product sales data and customer visit. With the features provided by Lazada, it makes a positive value for E-Commece Lazada according to Drooms Store as one of the sellers on Lazada. Due to their excellent analysis of this business, Drooms Store did not bother to create business reports that can be time consuming.

e. Monitor real time which is a feature of daily business reports provided by Lazada to all sellers. This feature is a favorite feature for B if Dadang as the owner of the Drooms Store, because when entering this feature and the revenue figure on the monitor is very high, it makes selling enthusiasm high too, whereas if the number shows a low nominal, it makes us think how to 
improve. sales. Many reports are provided by Lazada Business Analysts to improve sales methods, create promotions, or product selection. For example, in the case of a few days ago, after the 12-12 December 2020 promo, the owner of store will get from Lazada business analysts, so that the owner of store can take some anticipatory steps on the development of their products sold on Lazada.

\section{CONCLUSIONS AND RECOMMENDATIONS}

The results of this study explains that s Strategy of product selection is the most important thing for the check-out or sale of products to consumers, by focusing on the scale of benefits, which is the market price and the activities of research products. Product advertising strategy which is an advanced strategy after product selection. There are things that must be done so that the product can have a high exposure from consumers such as the appearance of the product or product photos must be good and attractive, the naming of the product must be attractive and specific, the decoration in the shop must be attractive and make it easier for consumers to check out, and make an approach to consumers with consumer chat in order to provide reviews of the products we sell or give vouchers for free as loyalty to consumers to keep shopping at the seller's store (Droom Store). The Analyst Business Strategy is a way for Droom Store to measure products and their promotions whether they are successful in attracting consumers or not, so that with business analysts, Droom Store can easily make decisions about the products they sell and what promotions they will make for reach consumers and convert them into sales.

Recommendations from the results of this study to the Droom Store as a seller at Lazada E-Commerce are consumer services including serving in terms of chat provided by consumers to be replied to more quickly in order to improve services provided by sellers to consumers and handling problems with products that have no sales, decrease in sales and so on so that solutions are provided to speed up product resale.

\section{REFERENCES}

Budhi, Galih Setyo. 2016. Analysis of the E-commerce System in Lazada Indonesia's Online Buying and Selling Company. Electronics, Informatics, and Vocational Education (ELINVO). 1 (2): 79-82.

Fenalosa, Aldo. 2018. Flashback of Ecommerce Platform in Indonesia 2018. https:/ /iprice.co.id/trend/insights/kilas-balik-e-commerce-di-indonesiatahun-2018/ (accessed December 13, 2020).

Iprice. (2017). Southeast Asia State of e-Commerce 2017.https: // iprice. co.id/insights/ stateofecommerce2017/ (accessed December 2020).

Iprice. (2019). Map of e-Commerce Indonesia. https://iprice.co.id/ insights / mapofecommerce / (accessed 14 December 2020).

Yes. 2011. "Implementation of E-commerce Based On Line Sales System In Unique Women Home Businesses". Jakarta: UIN Syarif Hidayatullah Jakarta.

Kusuma, Des Chandra. 2017. Becoming Rich In E-COMMERCE Business, Jakarta: PT. Gramedia Pustaka Utama. 
Lazada. (2019-2020). Seller Center. https://sellercenter.lazada.co.id/ apps / seller / login? redirect_url $=$ https\% 3A\% 2F\% 2Fsellercenter.lazada.co.id\% 2F (accessed January 1 to December 13, 2020).

Naraya, Gisa. 2017. JACK MA: Trillion Yuan Human, Yogyakarta: Genesis Learning.

Ramdhan, Henndry.E. 2016. Startup Business Model, Jakarta: Penebar Plus (Self-Help Group Spreader).

Reza, Faisal. 2016. Lazada.co.id On Line Sales Promotion Strategy. Communication Studies. 4 (1): 64-74.

Suciani, Ratih Dwi. 2010. "E-commerce Business Competitive Strategy in Generic Alternative Options Strategy". Jakarta: University of Indonesia. 